\title{
Queering the Debate: Analysing Prostitution Through Dissident Sexualities in Brazil
}

\section{Amanda Álvares Ferreira*}

\begin{abstract}
The aim of this article is to contrast prominent discourses on prostitution and human trafficking to the context of prostitution in Brazil and local feminist discourses on this matter, understanding their contradictions and limitations. I look at Brazilian transgender prostitutes' experiences to address an agency-related question that underlies feminist theorizations of prostitution: can prostitution be freely chosen? Is it necessarily exploitative? My argument is that discourses on sex work, departing from sex trafficking debates, are heavily engaged in a heteronormative logic that might be unable to approach the complexity and ambiguity of experiences of transgender prostitutes and, therefore, cannot theorize their possibilities of agency. To do so, I will conduct a critique of the naturalization of gender norms that hinders an understanding of experiences that exceed the binary 'prostitute versus victim.' I argue how both an abolitionist as well as a legalising solution to the issues involved in the sex market, when relying on the state as the guarantor of rights to sex workers, cannot account for the complexities of a context such as the Brazilian one, in which specific conceptions of citizenship permit violence against sexually and racially marked groups to occur on such a large scale.
\end{abstract}

Keywords: Gender; Prostitution; Sex Trafficking; Queer Theory; Feminism; Travestis.

\section{Introduction}

'Prostitution' as an object of study can be approached through different perspectives that try to pin down exactly what are the social and political problems involved in it, and therefore how it can be dealt with by the State. In this sense, feminist curiosity upon this thematic usually involves an attempt to understand women's subordination and to understand the origins and reasons of exploitation of women. The aim in this work, by critically engaging with that thematic, is to understand the effects and possibilities opened up by different discourses on prostitution considering the background of travesti prostitution in Brazil and to understand how these localised experiences can produce insights on larger

Pontifical Catholic University of Rio de Janeiro (PUC-Rio), Rio de Janeiro-RJ, Brazil; a.alvaresf@gmail. com. ORCID iD 0000-0002-5563-6001. 
power structures. It is my intention to look at travesti prostitutes' bodies as making possible the subversion not only of gender norms but also of a Brazilian morale that hangs on a thin line between tolerance of subjects marked racially and sexually, and an underlying necessity to violate and exclude these bodies, or, many times, to kill them.

The word travest $i^{1}$ derives from transvertir, meaning to transform or alter the style, nature or essence of someone or something. Being a travesti is not simply about crossdressing, or drag performing, but adopting feminine names and pronouns, hairstyle, clothing style, cosmetic practices, ingesting hormones and applying silicone directly into their bodies. Don Kulick (1998) affirms that travestis do not self-identify as women, and therefore they would configure a specific combination of female physical attributes and male homosexual subjectivity. However, I would be reticent to simply state that travestis' subjectivities are reducible to a male homosexual recognition: even though they do recognise they are not precisely what heteronormativity says it means to be a woman, most of them do not recognise themselves as 'gay men.' On the contrary, travestis do pursue and adopt a transsexual identity but most of them do not go through so-called 'corrective' surgeries, and do not wish to do so. In this sense, answering what is the gender of travestis is rather difficult without falling into dangerous generalisations (Pelúcio 2005).

What I would like to emphasise is that travestis' experiences and performances cannot be reduced to universal and monolithic explanations. This is so because, first, travestis' subjectivities are too multiple, and there is most certainly a gap between those who have managed to fight for their rights and militate on a national level to denounce violence committed against trans people in Brazil, ${ }^{2}$ and those at sites of subalternity, of extreme marginalisation and poverty.

Anyhow, observing how varied travestis' experiences can be is important because giving voice is not the simplest part of a feminist project. There is always a difference between considering marginalised women's experiences in feminist theory and actually managing to give voice to (or listening to) people in sites of marginality and subalternity: 'When we (finally) give marginalised people voice, we really give ourselves microphones through which to broadcast Western subject-centred egoism' (Spivak and Mohanty, cited in Sylvester 1996: 264). To avoid that, it is necessary to focus on the contradictions of universalistic explanations and to deconstruct naturalised binaries upon which our knowledge is built. In other words, this will mean translating this coproduction and transforming it to think local stories and engage differences theoretically in a spatially and historically localised manner (Pereira: 2012).

This requires understanding the social and historical construction inherent to these pairs (such as prostitute versus victim) to be able to deconstruct them, as proposed in Judith Butler's work (2016). The choice for a queer perspective is based precisely on its proposition of embracing deviation, of straying from the norm and opening the possibility of alliance in difference, and of not taking fixed identities as a point of departure. However, to manifest this difference without falling into the repetition of preceding authoritarian practices requires caution. Generalising moves in fighting compulsory heterosexuality and mining easy binaries without proper contextualisation can end up, according to Pedro 
P. G. Pereira (2012), in a rushed approach that integrates different positions in a homogeneity. In his terms, away from the context of enunciation and without proper attention to the singularity of each theoretical body, we would simply reproduce theories - in a repetitive movement from centre to margins - rejecting the resistance of the realities analysed by these very theories.

\section{Reading prostitution through human trafficking discourses}

I introduce different discourses on prostitution and sex-trafficking, both abolitionist and pro-sex work, to address the main (agency-related) question that is underlying both of them: can prostitution be freely chosen? Is it necessarily exploitative? It becomes essential, then, to understand how abolitionist arguments can actually contradict a feminist political project (HoSang and Yamin 2016). My argument is that, as stated above, discourses on prostitution, departing from sex trafficking debates, are heavily engaged in a heteronormative logic that does not approach the complexity and ambiguity of experiences of sex work and cannot theorise possibilities of agency, especially when looking at contexts such as the Brazilian one.

It was in the $1990 \mathrm{~s}^{3}$ that debates around trafficking re-emerged, with a rhetoric of 'modern slavery' that focused on the growing porosity of national borders (and international criminal organisations' evolution due to it) and deviant gender norms (HoSang and Yamin 2016: 392), but which did not necessarily follow a huge increase in the flows of trafficked people. ${ }^{4}$ As an ambiguously defined term that collapsed migration, organised crime, prostitution, sex trafficking and sex work, and human rights, 'human trafficking' seemed even more difficult to be practically handled due to the insufficiency and unreliability of data (even though statistics are still largely used by scholars trying to describe the scope of the problem).

Different researchers and activists, concentrated mainly in the global North, and organised in non-governmental organisations (NGOs) or international organisations (Aradau 2008), tried to pin down the truth on sex trafficking and the global sex trade. It is in this well-known context that the broadly cited split between feminists - between those who see prostitution as sexual slavery and those who see it as labour - takes place.

In this section, I will analyse overlaps between local discourses and abolitionist views: anti-prostitution (and anti-trafficking) works and efforts such as Kathleen Barry's (1995, 1997), as well as Catherine MacKinnon's (1993), contributions along with the Coalition against Trafficking in Women (CATW). These works seem in line with the (surprising) alliances between abolitionist feminists and evangelical militants, all of them with an approach that deems prostitution to be degrading to women. This position considers prostitution and sex trafficking as the same phenomenon, the only difference being that the last one involves crossing borders. Prostitution, therefore, can only be part of and result of a continuum of violence: from violence inscribed in social and economic structures to actual physical violence (Aradau 2008: 30). 
This line of argument is largely criticised for denying any agency and self-determination to women; it considers prostitution as an expression of women's subservient roles, their inferior social and political status. My intention, however, is not to reduce it to 'one monolithic explanation of violence to women' through abolitionist arguments (Kempadoo 2001: 28). Adopting an argument in line with the Global Alliance against Trafficking in Women (GAATW) (n.d.) also shows itself unsatisfactory in different ways, when looking at it from a Third World perspective. As I argue, both solutions to the question of prostitution rely on the state as the guarantor, but what remains unanswered is: what is the relationship prostitutes can have to a state and a society marked by certain racial and sexual conceptions and stigmas imposed on prostitutes? How can we understand sex worker's agency when they are in such marginalised context?

Travestis' experiences are here considered as dissident sexualities that inform the Brazilian imaginary. First of all, their existence and subjectivity, in their multiple experiences, are challenging in several ways: challenging universalistic answers to patriarchal domination of women, to prostitution and victimhood, as well as opening the possibility of questioning binaries upon which our knowledge about 'man' and the State are built; and undermining the very category of woman, which shows the fragility of gender norms and puts into question, as proposed in Butler's work (2016), the reach of the feminist political project. Travestis' marginal resistance to norms of both sexuality and race is here framed as a queer questioning of our model of modern society.

In this context, according to Larissa Pelúcio (2005: 223), prostitution is usually understood in an overlap and dialogue between: (a) a discrediting and degrading activity, with which travestis only engage out of necessity, and which they would leave it as soon as possible; (b) as a way of ascending socially and achieving material and symbolic conquests; or (c) as work, as a form of generating income and as a sociability site.

With this basic schema in mind, it is possible to begin to comprehend how multiple and contradictory are these transgendered experiences of prostitution (and of gender performances). As Berenice Bento (2016) affirms, the generalised heterosexism in feminist theories made it unable to listen to voices oppressed by another kind of exclusion - that of divergent sexualities and bodies. I consider how bodies of travestis, in violating rules that define what it is to be a man or what it is to be a woman, put discourses in dispute: when discourses try to dissipate ambiguities, (travesti) prostitutes' voices are silenced. In this sense, denaturalising accounts of individual subjectivity as to analyse relations of force, violence and language that compose (our) bodies, especially ones deemed abnormal, will provide us a background to think their agency. This will be done by looking at how the reproduction and challenging of norms by these marginalised bodies perfect and/or subvert conceptions which are deemed natural - and, with this move, show their artificiality.

\section{Notes on trafficking of Brazilian travestis for sexual exploitation}

According to the Palermo Protocol of 2000, the Protocol to Prevent, Suppress and Punish Trafficking in Persons Especially Women and Children, which supplements the United 
Nations Convention against Transnational Organised Crime (UNGA 2000), and which Brazil ratified, trafficking in persons:

shall mean the recruitment, transportation, transfer, harbouring or receipt of persons, by means of the threat or use of force or other forms of coercion, of abduction, of fraud, of deception, of the abuse of power or of a position of vulnerability or of the giving or receiving of payments or benefits to achieve the consent of a person having control over another person, for the purpose of exploitation. Exploitation shall include, at a minimum, the exploitation of the prostitution of others or other forms of sexual exploitation, forced labour or services, slavery or practices similar to slavery, servitude or the removal of organs (Palermo Protocol 2000).

Brazil's present legislation (Plano Nacional e Política Nacional de Enfrentamento ao Tráfico de Pessoas, decreto $n^{\circ} 5.948$, de 26/10/2006 e decreto $n^{\circ} 6.347$, de 8 de janeiro de 2008) (Brasil 2006, 2008) was adapted in accordance with the ratification of the Palermo Protocol. It is necessary to highlight, however, that it does not expressly consider vulnerability of LGBTTI $^{5}$ community to such crimes (Smith 2012), as becomes clear when it mentions 'women and children.'

Considering the widespread marginalisation and criminalisation of trans people in Brazil due to sexual, racial and class factors - due to the unacceptability of their bodies - two conditions generally call for attention when considering LGBTTI vulnerability to sexual exploitation by third parties: the common picture of instability in and rejection from the household environment, and discrimination in the work market. According to the NGO Associação Nacional de Travestis e Transexuais (ANTRA) (2018), 90\% of the trans population in Brazil is engaged in prostitution.

It is important to differentiate the terms of exploitation from the terms of trafficking: the fine line that separates them seems more like a question of the lenses through which the question is seen and interpreted. As mentioned above, even though there's a clear connection between migration and sex work, the numbers still seem (or always seem) very inaccurate to balance the situation (Pelúcio 2010). For example, the absence of specific notification as transfemicide when travestis and transsexuals are murdered make it even more difficult to map out the motivation of crimes and the circumstances of them. Estimates, many times, are based upon media information and denunciation on social networks (Bento 2016; Carvalho and Carrara 2015).

Several cases broadly publicized by the media of trafficked trans people report networks that alienate people from the North and Northeast regions of Brazil and traffic them to be exploited in the Southeast (Girão 2013; G1 2013; Monteiro 2014). But these news reports seem somewhat rare in comparison to cases of those who willingly left their home towns for cities like São Paulo, Rio de Janeiro, and Brasília, or for Europe (Spain, Italy, Portugal). It is essential to recall, however, that leaving willingly, or migrating willingly, does not exclude violence, to which they are subjected in their daily lives. 
Since the 1970s (Kulick 1998), the flows of Brazilian travestis to Europe ${ }^{6}$ has been increasing, and this route usually means conquering significant changes in their lives and bodies: "transformation" as a permanent project of feminisation is inextricably linked to mobility, as a constitutive process of travestilidade itself'7 (Pelúcio 2010). Travelling to Europe, becoming Europeia, ${ }^{8}$ comes from the ideal of being beautiful and feminine, fine and sophisticated, being a diva instead of a viado de peito (slang for 'fag with tits'), as Pelúcio (2010) suggests. Going to Europe is the biggest dream of many travestis, as it means living an experience that would otherwise be impossible to Third World inhabitants. Even if they recognise there is still stigma and prejudice around migrants, and, especially, prostitutes, the risk (and the price they pay for it) seems worth it. Marguinha Minelli, a travesti who lived and worked in Paris, reports that, still, in Europe, men respect travestis and liked her a lot more 'as woman,' something she says would be unthinkable in Brazil (Pelúcio 2005: 242).

Still, the focus usually given by national media to travestis' trips to Europe remains human trafficking and imprisonment (Pelúcio 2005): a focus on their non-agency, on their unwillingness to migrate, which emphasizes and reiterates their invisibility based upon fragile data and 'common sense.' These discourses, of course, do not place them as the ideal victim of traffic, but in a space between victimhood and threat. While women and children are frequently pictured as a victimised category, vulnerable to threats and dangers and demanding of protection, travestis oscillate between being potentially dangerous (and also as perpetrators of trafficking in persons and prostitution, which they sometimes are) and being victims.

The colonialist focus international discussion has taken on the matter of trafficking in persons is marked by an obsession with irregular migrants, particularly those originating from poor countries (Piscitelli cited in Pelúcio 2010: 894). In this frame, class, nationality, race, and gender (and, especially, non-normative sexual behaviour) are contributing factors to the construction of otherness of these migrants. This otherness is enhanced by the frequent invisibility of transgender people's desires to migrate and work at the sex industry, in a 'victimising discourse known as trafficking' (Agustín 1988: 7). I reiterate, however, that this does not mean cases of trafficking (or exploitation, especially) do not exist - only that harsh laws against trafficking often exacerbate the plight of these sex workers. As Pelúcio states it, travesti prostitution in Europe is not fed by trafficking in human beings, but by the material and symbolic oppression that circumscribe them, making their access to education and work more difficult, and compromising their projects of transformation and insertion outside of the sphere of prostitution (Pelúcio 2005: 243).

With this in mind, it is essential not to take as a premise that prostitution is always and intrinsically violent and exploitative, but why and how it is so, and why discourses related to prostitution and transgender bring a rhetoric of heroism against 'people whose activities are considered deviant' (Agustín 1988: 7). 


\section{Abolishing prostitution of women's sexuality?}

From the radical conservative (radcon) point of view, it is absurd for someone defend women who may sell pleasure to a man, negotiate that pleasure, put a price to it. Give profit to a boss, ok, submit to terrible work conditions, ok, but sell pleasure and dare to enjoy it, never! [...] To the radcon, the prostitute will always be the victim, always 'exploited' by the perverse man, also known as your client. [...] I sit, lament and cry, but I prefer to give voice to us prostitutes, listen to our own stories and demands, fight so that we can have full condition of choosing the path we want, following prostitution being one of them. Nobody here believes, in their own minds, that they will live to see the end of prostitution. The most urgent, thus, is to fight for better conditions for those who are in the activity to be able to exercise it in safety, with better remuneration, without the weight of stigma (Moira 2016: 58).

I introduced the discussion on trafficking and prostitution in order to question whether prostitution is necessarily a violence, and to bring in travestis' dissident sexualities as an abject subjectivity that challenges present discourses and solutions to the global sex trade. My aim is to understand how these discourses are heteronormative in such a way that they need to produce an otherness (that is still within these discourses' regulation) of deviant sexual behaviours in order to establish heteronormativity itself hierarchically and limit the borders of a (female-based) feminist project.

I will work with the abolitionist logic based mainly on the classic approaches by Barry (1995, 1997) and MacKinnon (1991, 1993, 2009) and their interconnection with present abolitionist discourses in Brazil. It seems important, first of all, to quote Barry's work because it is broadly cited as a reference for abolitionist views and because it understands prostitution as a (gendered) human rights violation. Sex would be 'an integral dimension of the human being that is to be accorded the respect, dignity and rights inherent in being human'9 (Barry 1997: 29). Therefore, when sex is made into a commodity, sold and purchased, the human being is violated.

Once defined as an abuse of human rights, the abuses of sexuality are seen as a result of power structures that make them possible in systematic and institutional levels: when sex is used for financial or personal gains, it results in harm and dehumanisation. In this sense, once the actual harm is identified (in an objective manner, according to the author) it does not matter if the victim declares consent or not, as they are distinct facts. While in rape or sexual harassment there is no consent, in prostitution and pornography there might be - still, in all cases, there is a harm to human dignity (besides being prejudicial to women's physical and mental health), and that is the objective fact about it. This would explain why activities such as sex trafficking and prostitution can be merged into one category: both of them are violations of human rights and women's integrity, no matter if the victim consents or not. 
Barry (1997) affirms that trafficking in women, military prostitution and the mass marketing of sex are phenomena generated and made global by the normalisation of sexual exploitation and producing the 'prostitution of sexuality' as a model imported from the United States and other Western states. At a certain level, there is a social sanctioning of sexually exploitative measures over women's bodies, turning such practices acceptable, and making possible individualist explanations of women's agency and desire for the sex work industry (while they would actually be victims). She claims that abuses are reinforced by industries (such as the pornography industry) and technologies, whose actions make harm increasingly normalised: these exploitative practices over human sexuality become desire, are made normal.

This process is what allows consumers of prostitution sex to be seen as normal, as they promote the universal class condition of women's sexual subordination through the impact of the global free market economy that makes anything merchandise. The normalisation of prostitution in the United States and Western post-industrial countries through the media and advertising, pornography and the promotion of teenage sex, according to Barry, makes 'normal sex' more and more undifferentiated from prostitution sex, and spreads to newly-industrialised countries to help the promotion of the sex industry and trafficking of women for brothels and forced marriage.

Moreover, as long as Western liberal and legalistic approaches continue to distinguish between free and forced prostitution, women's victimisation would be reiterated, and their perspectives for looking for help and therapy to rebuild their lives would become more distant. For example, while women who are trafficked into a country for sexual exploitation are treated in a different manner from prostitutes who are already there, these last one's exploitation would become more legitimised and more and more normalised. For these reasons, Barry calls upon states to penalise all those involved in prostitution-related activities, denying any laws that legitimise prostitution of any person and any distinction between free or forced prostitution, or any attempt to legalise it as a profession.

Facing that, HoSang and Yamin (2016) have importantly noted the parallels between such abolitionist narratives and the widespread panics in the early twentieth century over 'white slavery.' ${ }^{10}$ In both cases, (white) female vulnerability is emphasised in contrast to the savagery and unrestrained sexuality of men (of colour) in order to justify 'rescue' initiatives. The response from the State to this vulnerability is also gendered: the masculinist state must intervene through law enforcement in order to prevent these unrestrained men from committing such crimes against victimised women; while it should also provide the means for other (empowered and white) women to restore the wounds of these vulnerable women. These discourses, demanding and relying on law enforcement to dismantle networks of sex work and providing support for 'rescued' sex workers, help produce an ideal victim, a 'mythical female subject of trafficking in women' (Doezema, cited in HoSang and Yamin 2016: 394), that is constructed precisely through sexual vulnerability. This victimised subject depends on the heroic actions of abolitionist (white) females (and the State) to rescue them and bring them back to freedom. 
The most obvious observation that comes to mind is: how to end this prostitution of sexuality if the State is, most times, the very agent of (political and physical) violence and perpetrator of the marginalisation of these bodies, be they migrants or not, and if law enforcement against prostitution seem to actually enhance prostitutes' marginalisation? When looking at travestis' experiences of sex work, not only is there lack of legal support for them, through the lack of acknowledgement of their gender identity in police reports, ${ }^{11}$ for example; but, most importantly, the frequent cases of police violence against them, which is accompanied, most times, by legal impunity. One example to quote here is in Kulick's (1991) ethnography on the lives of travestis: the case of a policeman in Rio who was convicted, in 1994, by a court of military justice for killing a travesti with one shot to her face and two shots to her back. He was also under investigation for the death of five other travestis, who also had their genitals cut off. His sentence was reduced from twelve years to six because the victim was, according to the judge, engaged in a high-risk activity - therefore she was not taken by surprise. 'Travestis working as street prostitutes, in other words, are asking for it, and no one should expect courts to unduly penalise a man just because he shoots travestis in the face' (Kulick 1991: 30-31).

What seems to be underlying such narratives about 'rescuing' women in name of their human integrity is, in fact, a reiteration of the subject position of a Western feminist in contrast to the subject prostitute as a victim and silenced other. The Western feminist embodies, in this sense, a project of saving 'other' women, assuming an inherently masculinist position of protector; in a binary where the protected are constituted as necessarily without agency. Considering that, it makes no sense to 'save' women so that they would be recognized as subjects, with agency, for this would undermine the very subjectivity of the Western feminist who saves them (Penttinen 2008). Penttinen associates the reiteration of this binary with the results that prohibitive policies and law enforcement have in actually turning those engaged in prostitution more vulnerable, instead of the opposite (Penttinen 2008: 18). In another interpretation, the rhetoric of 'women saving other women' is constructed upon a progressive narrative that places those who save in an enlightened position, contrary to those who need to be saved. Anyhow, this is still a masculinist move which places some women's knowledge as critical and superior. ${ }^{12}$

It was also during the 1990s, according to Adriana Piscitelli (2012), that the heterogeneous debate on sex tourism and prostitution gained visibility in Brazil, in a moment in which feminisms were under strong debate, gaining space in the political scenario of the reformation of democratic institutions after the end of the military regime. Readings of prostitution under a negative rhetoric gained attention, as it was more and more linked to sex tourism and international sex trafficking. New transnational feminist movements (against sexist violence, against poverty) also gained strength in the country, such as the Slut Walk (Marcha das Vadias) and the Women's World March (MMM, Marcha Mundial das Mulheres). Meanwhile, different prostitute organised groups, such as the Rede Brasileira de Prostitutas (Brazilian Network of Prostitutes) (n.d.), the NGO Davida (n.d.), ${ }^{13}$ the Federação Nacional das Trabalhadoras do Sexo (National Federation of Sex Workers) and also the first political travesti organisations in Brazil, such as the Associação de Travestis e 
Liberados do Rio de Janeiro (ASTRAL), founded in 1992, and the Associação Nacional de Travesti e Transexuais (ANTRA), founded in 2000, all marked their presence in proposing regulation and legalisation of prostitutes rights and, in the case of the last organization, fought for the prevention of AIDS and other sexually transmitted diseases.

It is worth calling attention to the part played by Marcha Mundial das Mulheres in Brazil, a movement formed in 2000, and which is aligned with Marxist and abolitionist ideals (Piscitelli 2012). In 2016, before the Olympic Games in Rio de Janeiro and when lots of debate was generated around sex tourism and prostitution, the MMM in Rio launched a pamphlet: 'Offensive against the Mercantilisation of Women's Bodies' (Marcha Mundial das Mulheres 2016). In this document, events such as the 2014 World Cup and 2016 Olympic Games are cited as capitalist and patriarchal strategies for the commercialisation and exploitation of women's bodies: at these moments, the exploitation and banalisation of women's bodies is enhanced and made conventional to the society, as women are put for sale and subjected to men's domination.

The pamphlet also declares the MMM against the Gabriela Leite Law proposal ${ }^{14}$ proposed by congressman Jean Wyllys ${ }^{15}$ and states that: it is against the normalising by patriarchal capitalism of a form of patriarchal sexuality, with the objective of augmenting the market and control over women's sexualities; against treating prostitution as a result of individual behaviour (and not part of an organised institution); and that it considers the argument of women's sexual freedom hypocritical, in face of the androcentric character of sexuality.

Hence, regulating prostitution would mean legitimating the practice of prostitutors (which includes both those who promote it and men who consume it). The Marxist teleological view adopted by the MMM, working for the end of violence against women and against the sexual division of labour, claims the State must take action to put an end to the violence and discrimination that women suffer in face of prostitution, and also demands retirement from prostitution as a policy for those women who were subjected to such practices.

This brief representation is one small example out of many abolitionist approaches in the Brazilian context, less or more radical, institutionalised or not. More radical approaches are commonly associated with militants who identify themselves as 'radfems' or radical feminists (and, sometimes, even as TERFs, or trans-exclusionary radical feminists) (Carvalho and Carrara 2015). These radfem discourses ${ }^{16}$ have, frequently, when faced with the growth of transsexual participation in feminist debates with emphasis on the context of prostitution and militant HIV-prevention, adopted a position that does not recognise the integration of transsexuals into the feminist movement (Bento 2006). Not only do radfems not consider transsexuals 'properly women,' and because of this would not share the same vulnerabilities, but also the latter would be invading a feminine safe space and be threatening these women by 'pretending to be vulnerable.' Any empathy towards them, consequently, would be some kind of betrayal - travestis and transsexuals destabilise the discourse of protection of women by women. 
As Bento (2014) puts it, the feminine represents within such discourses what is devalued socially: when femininity is embodied by bodies that were born with a penis, there is an overflow of people's collective consciousness that is structured upon the belief that gender identities are an expression of hormones and chromosome arrangements. This overflow, or excess, means that there is no conceptual (or linguistic) apparatus that justifies and explains the existence of trans people: they are unintelligible.

These discourses against the participation of trans-persons in feminist debates - and, by the same token, in debates about prostitution - construct transsexuality as an exclusive matter of sexuality, and not gender, and builds male homosexuality upon a basis of misogyny. Women would be, therefore, at the centre of male homosexuality, or, the reason why it was generated. As Butler (2011) affirms, understanding male-to-female transsexuality, cross-dressing, or drag as such would follow the same logic as affirming that a lesbian is as she is because she had bad experiences with men, or has not yet found a proper man.

What is to noticeable in these discourses is that they understand being a woman as the result of sexual harassment - becoming a woman depends precisely on heterosexuality. This movement inscribes heteronormativity at the heart of the radical feminist argument. The attempt is to delineate prostitution as a gendered violence, as sex inequality, because of the fact that 'prostituted women and the transgendered are more likely to be physically or sexually assaulted than are men prostituting as men' (Mackinnon 2009: 293). Instead of opening the possibility for women's liberation through the investigation of the male point of view that creates the world in its own image (Mackinnon 1991: 118), it reinforces the very logic to which they are trying to escape.

The reason why prostitution is unacceptable in a radical feminist approach, in line with MacKinnon's (1991) work, is because prostitution, as well as rape, incest, sexual harassment and pornography are not only abuses of physical force and violence, but because they are abuses of women, and abuses of, most importantly, sex. It is through these practices that sex inequality is instantiated. Contradicting pro-sex-work approaches, MacKinnon affirms that even though women may choose to prostitute themselves, they would be doing it out of lack of choice:

The coercion behind it, physical and otherwise, produces an economic sector of sexual abuse, the lion's share of the profits of which goes to others. In these transactions, the money coerces the sex rather than guaranteeing consent to it, making prostitution a practice of serial rape. In this analysis, there is, and can be, nothing equal about it. Prostituted people pay for paid sex. The buyers do not pay for what they take or get. It is this, not its illegality, that largely accounts for prostitution's stigma (Mackinnon 2009: 274).

MacKinnon (2009) points out that the structure of prostitution derives from colonialism and, therefore, poverty, abuse and stigma are congenital characteristics of those who are prostituted. By the same token, the reason why there are mostly women and transgender persons engaged in it is exactly because it is, as I mentioned above, a gendered vio- 
lence. This is based upon a view that sustain that gender is basically the process through which women come to identify themselves as sexual beings that exist for men, and specifically for male sexual use.

Therefore, to become a woman depends on this violence to which women are subjected by men - femininity depends on masculinity to exist. First sexual (heterosexual) intercourse is a commonly definitive experience of gender definition (Mackinnon 1991: 111 ), for male dominance is sexual. In agreement with that, the question is not if prostitution is consented to by the parties involved or not, or if it is legal or illegal (it should be illegal, to this approach), but that these practices are largely permitted: 'as women's experiences blurs the lines between deviance and normalcy, it obliterates the distinction between abuses of women and the social definition of what a woman is' (MacKinnon 1991: 113).

This move, instead of creating a possibility for women's resistance through a critical view towards 'male knowledge and objectivity', or through lesbianism, ${ }^{17}$ reiterates heterosexuality as the primary form of sexuality. And gender, thereafter, is the concealed effect of these heterosexual relations. In this logic, the feminine gender is always in a submissive condition to the dominant masculine gender; and, in this framework, sex inequality configures itself.

MacKinnon maintains that there is no possibility of gender outside of this subordinating and exploitative form of sexuality. But, taking on Butler's questioning, can we conceive of the inequality of sexualisation without a prior conception of gender, without an idea of what men and women are (Butler 2004: 53)?

Butler (2004) claims that, in proposing, as does MacKinnon, such a systemic character of sexual subordination that would demand a regulation of sexual abuses, another kind of regulation is instituted:

[...] to have a gender means to have entered already into a heterosexual relationship of subordination; there appear to be no gendered people who are outside of such relationships; there appear to be no nonsubordinating heterosexual relations; there appear to be no nonheterosexual relations; there appears to be no same-sex harassment (Butler 2004: 54).

Hence, in MacKinnon's approach, certain expressions of gender are privileged in spite of others, and sexual harassment becomes the allegory of the production of gender. What remains unanswered, however, is how gender itself is regulated, producing masculine men and feminine women and continuously excluding other expressions outside of this binary. The subordination of women by men is part of a larger social practice that creates gendered bodies - and specific gendered embodiments are prioritised by such discourses.

Looking at this general framework of abolitionist views on prostitution, some conclusions should be taken into account. When proposing, by this logic, the prohibition of prostitution and related practices, with the aim of diminishing the abuse women suffer, certain ways of being women are privileged and reiterated (Butler 2004): the vulnerable female victim that exists to the extent that threatening men harass her. Instead of ending 
stigma around prostitution, it ends up reiterating it. Once you establish that femininity exists only in terms of masculinity, the possibility of agency and resistance to this system is undermined - prostitutes cannot speak for themselves because they are victims of this patriarchal structure.

This argumentation inherits a tradition in feminist studies, from authors such as Simone de Beauvoir (2009), that deem women's subordination to be universal. This finding of commonalities, at a first moment, seems like a political necessity in order to build a collective identity. However, the dangers of this conception are in an essentialisation of identities as well as victimisation of women, imprisoning feminist critical thought to a conceptual structure marked by a universal opposition to sex (Bento 2006). As women's interests are pictured as inferior due to a biological condition, universal positions are reinforced, and gender parts are essentialised to fix the identities of men and women. Gender, in this perspective, can be denaturalised, but it fails to be de-essentialised: in an effort to understand 'normal women' and find a common basis between them, a normalisation strategy is employed. Such a strategy is marked by certain (colonial) class conceptions and prejudices which blinds the strategy itself to its own processes of normalisation (Bento 2006: 80): it is necessary to recognise the ontological insufficiency of the term woman in order to use it strategically for a political demand, instead of reinforcing a supposedly natural essence of being female. As Haraway argues: 'there is nothing about being "female" that naturally binds women, itself a highly complex category constructed in contested sexual scientific discourses and other social practices' (Haraway 1991: 155).

By defending regulations to abolish prostitution, parameters of personhood are reiterated and this opens space for social punishment of transgressors of these gender norms. It seems like there is an underlying regime of bodies, ${ }^{18}$ in Nestor Perlongher's (1987) terms: as (transgendered) individuals use their body parts in practices that are not those prescribed by this matrix of power, they seem to threaten this well-sedimented structure upon which radical feminists build their theorisation. Being 'male' and being vulnerable would be incompatible, and being sometimes vulnerable and sometimes not would be even more so. It would also be in place to think about how this prescribes acceptable behaviours for women: adopting a dominant, agential position would be incompatible for prostitutes (or trafficking victims); claiming the right to exercise an activity deemed prejudicial to their bodies would be too.

Travestis in prostitution challenge these disciplinary regimes first by claiming agency in a position that would be reserved to victims; second, because of their ambivalent resistance and reiteration of norms, and also because they are subject to vulnerability even though they are 'males' in 'biological terms;' and third, because this gendered vulnerability is not one that is created upon a heterosexual relation.

According to an abolitionist approach, the solution to contain this gendered violence that remains so largely permitted through the global sex trade and pornography industry lies entirely within state violence and incapacitation of prostitution agents. Abolitionists claim the State should rescue vulnerable women and girls and punish their violators in order to assert its moral and ethical legitimacy (HoSang and Yamin 2016). Curiously, pro- 
sex work scholarship and activists ${ }^{19}$ also rely on the State as the guarantor of prostitute's rights, and as responsible for stopping abuse in the sex industry (such as in trafficking and exploitation), but their reliance on the state is articulated through legalisation. It seems necessary to propose a deeper investigation upon how the feminist subject here referred to is also constructed discursively by the political system it is trying to overcome. Therefore, as Butler (2016) suggests, an acritical claim to this system in the name of emancipation of women would be doomed to failure. Besides, on a queer perspective, it may be precisely the strength of disidentification, and embracing of difference, that is crucial for democratic contestation.

In pro-sex-work discourse though, the 'voluntary prostitute' is continuously referred to as a white (Western) sex worker endowed with agency, while poor, black (cis or trans) women at sites of marginalisation are still pictured as victims who need saving. As sex workers' movements present prostitution as a choice and defend sex work's profitability, their argument is in no way counter-hegemonic or radical. In a sense, they are not a form a resistance since they reproduce a neoliberal governmentality, defending principles of marketisation and consumerism by claiming their personal right to commodify their bodies. This takes place, however, through a delineation of a category of sex worker in an exclusionary manner. A real prostitute would be one who willingly chose to be so, and not someone who prostitutes her/himself in order to buy drugs due to an addiction or out of necessity because of irregular migration status, etc. The point is that this differentiation between real sex workers and drug addicts, or trafficked women, or ethnic others opens space for an othering, reinforcing the silence of vulnerable and abjected bodies (Pentinnen 2008).

\section{Conclusions or re-openings by subversive possibilities}

Throughout this article, my aim was, in summary, to complicate the debates over prostitution in order to think of how travesti embodiments can complicate how we think agency, and it can be so in a manner that put into tension the very norms under which we are built. Just as Pentinnen considers prostitutes inhabiting a zone of abjection, I can think of travestis occupying this same imaginary in Brazilian society (Pelúcio 2005; Peres 2012). Abject beings are those who are not yet 'subjects', but who form a constitutive outside of the domain of the subject (Butler 2011). The abject exists in precisely those unliveable and uninhabitable zones of social life, zones that are nevertheless densely populated. Without the abjected outside, then, the subject cannot constitute itself. Therefore, the abject is a constitutive outside of the subject that allows it to found itself in a move of repudiation. These exclusionary operations are necessary for subject formation, through the repudiation of all that is unspeakable, unsignifiable, and unintelligible.

The domain of abnormality and abjection is not the opposite of the subject; it is, 'after all, part of intelligibility; the latter [abjection] is the excluded and illegible domain that haunts the former domain as the spectre of its own impossibility, the very limit to intelligibility, its constitutive outside' (Butler 2011: xiii). Abjection is determined to perpetual 
failure - abjected persons' existence is a critical resource that opens possibility of rearticulating legitimacy and intelligibility, to renegotiate its borders and subvert them in a manner such to constitute their specific expression of agency.

Travestis' expressions outside of the sex/gender correspondence system tends to be treated as criminal, sinful, abnormal, or perverse, thus, abject. Their lack of intelligibility under existing norms turn them into bodies susceptible to exclusion and violence, into bodies that do not matter. But, as Pelúcio reminds us, they do matter: after all the abjected needs to be there, even if at a hygienic distance, to demarcate the borders of normality (Pelúcio, cited in Peres 2012). These demands, therefore, understanding how violence is not only exercised upon their bodies, but is also constitutive of them - understanding how bodies are killed and violated but also formed, gendered, and racialised through political violence.

Butler would suggest that, differently from the arguments so far presented in regards to prostitution, gender does not presuppose sexuality; and that engaging in any sexual practices does not designates gender. Under the logic of hegemonic sexualities, for example, how anal sex is practiced determines your position as a 'man' or not. This follows the same logic we presented in MacKinnon's (1991) argumentation, by which gender is an effect of sexuality. This logic is undermined by travestis expressions of femininities and ambivalent relations to it: sometimes reproducing the norms by which they are themselves violated, sometimes overcoming them (Butler 2011: 83). This happens, importantly, because what is exteriorised or performed can only be so by reference to what is already defined as a corporeal legibility.

This show us an ambivalent subject, one which is not unproblematically subversive, but also which does not obey universalisms and norms perfectly. It is this very space of ambivalence that allows us to understand how subjectivation works, and how it also fails. These re-articulations of hegemonic forms of power are what open up the possibility of resignification of the norms, 'and the reworking of "queer" from abjection to politicized affiliation will interrogate similar sites of ambivalence produced at the limits of discursive legitimacy' (Butler 2011: 84).

In a repetition that always fails to achieve ideality, again, is where the possibility of subverting the norm resides, and this is how I propose engaging with prostitution beyond the 'threatening men versus vulnerable victim' binary. Travestis and their transits are hybrid, they express marginal forms of desire which demand different problematisations about themselves, and this move puts into question social, political and cultural paradigms.

In an interesting link, Peres (2012) considers travestis' expression to be parrhesiastic: as analysed by Michel Foucault (2011) in his last course at the Collège de France in 1984, parrhesia means to have the courage to say the truth. To practice parrhesia means to bluntly say the truth to yourself, in such a way that truth is inevitably also brought to others, practicing a discourse that is frank independently of the consequences to be faced, such as Socrates practiced when he died for the truth. Travestis, in their subjectivation that oscillates through disciplines over their bodies and pleasures, emerge affirming their bold 
truths in face of the determinations of sex, gender, and desires. The marginalisation and violence to which they are subjected would be a confirmation of this parrhesiastic move: showing the truths of our present social and historical context, and about how our society works, would then be a form of resistance (Peres 2012).

Travestilidades are subversive or nomadic (Peres 2012) because of their capacity of exposing the artificiality of heterosexuality. But this exposure does not necessarily lead to subversion. There remains a possibility that heterosexuality augments its hegemony even through denaturalisation - these performances might re-idealise heterosexual norms, as many times they do. Anyhow, the point to be made is that this form of subversion is not one which liberates one completely from the norm. Instead, these ambivalent subjects show more clearly the effects of being embedded in regimes of power, and being constituted by them.

Heterosexual privilege, as Butler argues, also operates in a way that naturalises itself as the original and normal form of sexuality. This supposed originality of heterosexuality pathologises trans persons, as mentioned above, who aim for changes in their bodies in order to exercise a 'normal sexuality.' Opposing this argument of pathologisation, Bento (2006) affirms that, in fact, the modifications they conduct on their bodies are in order to find social intelligibility. This allows us to argue that these 'original' practices of gender are an imitation as well. Mimicry is also at the heart of the cisgenderism and heterosexuality: a cis woman performs an imitation as much as a trans woman. The difference lies on the fact that while travestis and transgendered individuals have to work in a relatively selfconscious way in order to build their identities, the (cis) others are under the illusion to be simply acting naturally. Trans crystallises and exposes many of the tacit understandings that guide the creation and maintenance of gender in our social life (Kulick 1998: 10), but both cis and trans gendered performances are informed by regulations that are re-enacted and that produce, retroactively, the appearance of gender as an abiding interior depth.

A consequence of this argument, however, is that resistance is never achieved in such a way that the norm is fully overcome. While travestis are subversive in many ways, their reiteration of the norm presents us with a paradox. They resist the disciplines over their bodies in order to perform gender practices that are deemed to turn them 'subordinate', as they reproduce stereotypes of femininity in their social, affective and sexual practices. This opens up a questioning in line with what Saba Mahmood (2005) proposes: if power is not a universal category, resistance and agency cannot be read as such. Agential capacity does not necessarily impose a teleology of progressive politics - travestis' agency may reside precisely in what seems to be a case of subordination and passivity, but it is through these practices that their resistance is possible. Because of this, I would argue that it is profitable to focus on their complex experiences and performances not exclusively as forms of resistance, but as forms of inhabiting norms, as Mahmood argues.

I would suggest that travesties are indeed in a condition of abjection, of unintelligible exclusion. In their search for a normality, they reproduce the same norms that exclude them. In their prostitution practices, they manage to build their bodies and learn how to perform their femininities, transgressing what had been previously assigned to their 
sexed bodies. At the same time, they (re)create rules and boundaries of what is feminine and what is not, aiming (not necessarily in a fully self-conscious way) to achieve normality. Analysing power structures from this point of view makes it clear that subjectivity has contradictory relations to race, gender and sexuality.

By way of conclusion, we can perceive how the agency of marginalized subjects (black cis and transsexual women, travestis, etc.) can remain continuously overlooked, and they can remain voiceless, in Spivak's terms, even by those who wish to 'rescue' them, and even if we look at locally produced discourses. The logics of rescuing and saving reproduces itself in different levels, which is why understanding agency in its ambivalences is a profitable path in order to think of prostitution.

The reiteration of binaries such as prostitutors versus prostituted, rescuing versus saved, etc., end up reproducing truths and hierarchies resulting from a Western epistemology, and reaffirms our (Latin) condition of subalternity, which recreates a logic of naturalisation of differences in our local context (Mignolo, cited in Pelúcio 2014). We carry historical and cultural marks of the discourses that produce ourselves as peripheral. Understanding how our colonisation is also epistemological in order to perceive both sides of a binary (cis and trans, in a different example) as product of the same system of power is a crucial step in order to exceed the limitations of present discourses, discourses which reproduce a global 'sex-race-capital system ${ }^{\text {'20 }}$ of regulation.

As much as we see progress in human rights, progress in the legislation for trans people's rights, ${ }^{21}$ progress due to the militancy of sex workers in favour of rights of prostitutes, it is necessary to question what the effect of law enforcement actually is. But if the law is evoked for a racial elite and not for a racial minority, or if the law privileged a group of women in spite of trans women, it is possible to map yet another system of power that works through this law. The question becomes, thus, if it is possible to work against this effect of the law and its regimes of power, and, therefore, how to exceed it.

\section{Notes}

1. I maintain the term travesti untranslated precisely because it is the specific term by which these women identify themselves. Their lives and experiences do not translate directly from 'transvesti' (cross-dresser). Therefore, I write it in Portuguese in order to demarcate the historically and locally specific use of the term.

2. E.g., Indianara Siqueira, Amara Moira, and others.

3. According to Claudia Aradau (2008), after the 1949 United Nations (UN) Convention for the Suppression of Traffic in Persons and the Exploitation of the Prostitution of Others, trafficking exited from the political agenda in Europe and the United States. It is important to note that, at this convention, it was stated that 'prostitution and the accompanying evil of the traffic in persons for the purpose of prostitution are incompatible with the dignity and worth of human persons and endanger the welfare of the individual, the family and the community' (UN 1949). The convention also proposes the fusion of the concepts of prostitution and trafficking in persons; the rejection of legal tolerance to prostitution and the compromise to criminalise it; and, also, it considers anyone involved in prostitution as a victim (Piscitelli 2012: 21).

4. In HoSang and Yamin's analysis on the Californian context of sex trafficking and violence, the authors call attention to the small number of trafficking victims and offenders identified by law enforcement, in contradiction to the expectations of anti-trafficking activists after the dramatic increase in anti-trafficking efforts with the Trafficking Victims Violence Prevention Act of 2000 (HoSang and Yamin 2016: 393). 
5. LGBTTI: lesbian, gay, bissexual, transexual, transgender, intersexual.

6. Larissa Pelúcio (2005) indicates that in 1980s, Paris was the most desired destination. In the 2000s Italy and the South of Europe became more desired regions.

7. Unless otherwise indicated, translations of Portuguese language sources are by the author.

8. Europeia is a slang term commonly used between travestis to refer to those who go to Europe to work.

9. Barry states that this approach is compatible with the 1949 United Nations Convention for the Suppression of Traffic in Persons and the Exploitation of the Prostitution of Others (Barry 1997: 43).

10. HoSang and Yamin analyse it facing the context of law enforcement in California, USA, through proposition 35.

11. Bento (2014) calls attention not only to lack of reporting of these crimes as gender-motivated, or even the mere recognition of their gender, but also to the frequent use by the media of the masculine pronoun (' $o$ ') when talking about travestis: ' $o$ ' travesti and not ' $a$ ' travesti. Their gender identities are not respected in the news about their death, the preparation of the body, or the death report. The murdered person is assigned an imposed gender. Alive or dead, bodies are understood and classified around the sex/gender system. It's crucial to reiterate how offensive this is for these individuals, independently of the will to go through surgery. On the occasion of the murder of Luiz Carlos Ruas, who died because of defending a travesti from two men in São Paulo last December 2016, travestis and transsexuals protested heavily on social media for the recurrent use of masculine pronouns by the media during the coverage of the events. This reflects their political fight for being treated, in all public instances, according to their preferred gender, as they adopt feminine names.

12. This rhetoric is compatible with MacKinnon's (1991) feminist approach that will be described further in this article.

13. Both the Rede Nacional de Prostitutas and the NGO Davida were created by Gabriela Leite, a sex worker and feminist militant who became widely known in Brazil for her fight in favour of the regulation of prostitution.

14. This law project proposed the regulation of prostitution and pimping in Brazil. Its aim is to extinguish sexual exploitation and limiting the profits of third parties over prostitutes' bodies (Chamber of Deputies [Brazil] 2012).

15. Jean Wyllys is a congressman from the leftist party PSOL (Partido Socialismo e Liberdade, Socialism and Liberty Party).

16. Moira (2016) cites radcon (radical conservative), as in the quotation at the beginning of this section. The commonality between radfem and radcon discourses is the positioning against prostitution. Besides that, discourses more or less excluding of transsexuals are also related to these approaches.

17. According to MacKinnon (1991), feminism provides the epistemology of which lesbianism is an ontology.

18. Nestor Perlongher, in his visionary and illuminating ethnographic-queer work on the prostitution of men (michês) in São Paulo in the 1980s, mentions a regime of bodies concerning official recommendations about AIDS during the height of the disease at the time. Analysing the recommendations, he argued that there was a certain hierarchical organisation of bodies according to their proper function: the mouth to eat, the penis for the vagina, etc. Alternative uses for bodies were considered unnecessary, especially when considering anal sex (Perlongher 1987; Pelúcio 2014).

19. As mentioned above, in Brazil, cis and trans prostitutes articulate to defend their rights. Prostitution is not prohibited according to local legislation, but it is not regulated and recognised as a profession.

20. Term first cited by Beatriz Preciado, and quoted by Pelúcio (2014) in her work on queer translations and torsions to Brazil.

21. In 2016, President Dilma Rousseff signed the social name law (Brasil 2016). 


\section{References}

Agustín, Laura María. 1988. Sex at the Margins: Migration, Labour, Markets and the Rescue Industry. London and New York: Zed Books.

Associação Nacional de Travestis e Transexuais (ANTRA). Mapa dos assassinatos de travestis e transexuais no Brasil em 2017. At https://antrabrasil.files.wordpress.com/2018/01/relatc3b3rio-mapados-assassinatos-2017-antra6.pdf [Accessed on 2 October 2018].

Aradau, Claudia. 2008. Rethinking Trafficking in Women: Politics out of Security. New York: Palgrave Macmillan.

Barbosa, Ana Carolina Santos and Ivan Ignácio Pimentel. 2011. 'Dos Dias de Glória aos Dias da Glória: a Questão da Prostituição de Travestis na Avenida Augusto Severo.' In Miguel Angelo Ribeiro; Rafael da Silva Oliveira (eds), Território, sexo e prazer: olhares sobre o fenômeno da prostituição na geografia brasileira. Rio de Janeiro: Gramma.

Barry, Kathleen. 1995. The Prostitution of Sexuality: The Global Exploitation of Women. New York: New York University Press.

1997. 'Prostitution of Sexuality: A Cause for New International Human Rights.' Journal of Personal and Interpersonal Loss: International Perspectives on Stress and Coping 2 (1): 27-48.

Beauvoir, Simone de. 2009. O Segundo Sexo. Rio de Janeiro: Nova Fronteira.

Benedetti, Marcos. 2005. Toda Feita: O corpo e o gênero das travestis. Rio de Janeiro: Garamond.

Bento, Berenice. 2006. A Reinvenção do Corpo: Sexualidade e Gênero na Experiência Transexual. Rio de Janeiro: Garamond.

2014. Brasil: país do transfeminicídio. At http://www.clam.org.br/uploads/arquivo/Transfeminicidio_Berenice_Bento.pdf [Accessed on 25 January 2017].

Brasil. 2006. Decreto no 5948, de 26 de outubro de 2006. Política Nacional de Enfrentamento ao Tráfico de Pessoas. Brasília, DF. At http://www.planalto.gov.br/ccivil_03/_ato2004-2006/2006/Decreto/ D5948.htm [Accessed on 2 October 2018].

2008. Decreto $n^{\circ}$ 6347, de 8 de janeiro de 2008. Plano Nacional de Enfrentamento ao Tráfico de Pessoas. Brasília, DF. At http://www.planalto.gov.br/ccivil_03/_Ato2007-2010/2008/Decreto/ D6347.htm [Accessed on 2 October 2018].

2016. Decreto no 8727 , de 28 de abril de 2016. Dispõe sobre o uso do nome social e o reconhecimento da identidade de gênero de pessoas travestis e transexuais no âmbito da administração pública federal direta, autárquica e fundacional. Brasília, DF. At http://www.planalto.gov.br/ccivil_03/_Ato2015-2018/2016/Decreto/D8727.htm [Accessed on 02 October 2018].

Butler, Judith. 2004. Precarious Life: The Powers of Mourning and Violence. Londres: Verso.

2004. Undoing Gender. New York: Routledge.

2011. Bodies that Matter: On the discursive limits of sex. New York: Routledge.

2016. Problemas de Gênero: Feminismo e subversão da identidade. Rio de Janeiro: Civilização Brasileira.

Carvalho, Mário Felipe de Lima and Sérgio Carrara. 2015. 'Ciberativismo Trans: Considerações sobre uma Nova Geração Militante.' Contemporânea 13 (2): 382-400. 
Chamber of Deputies [Brazil]. 2012. Projeto de Lei - Lei Gabriela Leite. At http://www.camara.gov. br/proposicoesWeb/prop_mostrarintegra?codteor=1012829 [Accessed 2 October 2018].

Davida. n.d. Davida: Prostituição, Direitos Civis, Saúde. At http://www.davida.org.br/ [Accessed on 2 October 2018].

Enloe, Cynthia. 2014. Bananas, Beaches and Bases: Making Feminist Sense of International Politics. Berkeley: University of California Press.

Foucault, Michel. 2011. A Coragem da Verdade: O Governo de Si e dos Outros II. São Paulo: Editora WMF Martins Fontes.

1988. História da Sexualidade I: A vontade de Saber. Rio de Janeiro: Edições Graal.

2008. Segurança, Território, População. São Paulo: Martins Fontes.

G1. 2013. 'CPI ouve travesti que comandava rede de exploração sexual em Jundiaí.' 4 July. At http:// g1.globo.com/sao-paulo/sorocaba-jundiai/noticia/2013/07/cpi-ouve-travesti-que-comandavarede-de-exploracao-sexual-em-jundiai.html [Accessed on 2 October 2018].

Gilman, Sander L. 1985. Difference and Pathology: Stereotypes of Sexuality, Race and Madness. Ithaca: Cornell University Press.

Girão, Ivna. 2013. Travestis na mira do tráfico de pessoas em Fortaleza. Diário do Nordeste, 25 April. At http://diariodonordeste.verdesmares.com.br/cadernos/cidade/travestis-na-mira-do-trafico-depessoas-em-fortaleza-1.267255 [Accessed on 2 October 2018].

Global Alliance Against Trafficking in Women (GAATW) (n.d.). At http://www.gaatw.org/ [Accessed on 1 October 2018].

Haraway, Donna J. 1991. Simians, Cyborgs and Women: The Reinvention of Nature. New York: Routledge.

Hosang, Daniel Martinez and Priscilla Yamin. 2016. 'Constructing the sex trafficker: spectral figures and sexual violence in California's Proposition 35.' New Political Science 38 (3) 390-410.

Inayatullah, $\mathrm{N}$ and David L Blaney. 2004. International Relations and the Problem of Difference. New York: Routledge.

Kempadoo, Kamala. 2004 Sexing the Caribbean: gender, race, and sexual labor. London: Routledge.

2001. 'Women of Color and the Global Sex Trade: Transnational Feminist Perspectives.' Meridians 1 (2): 28-51.

Kulick, Don. 1998 Travesti: Sex, Gender and Culture and Brazilian Transgendered Prostitutes. Chicago: The University of Chicago Press.

Lykke, Nina. 2010. Feminist Studies: a guide to intersectional theory, methodology and writing. New York: Taylor and Francis.

Mackinnon, Catherine A. 1993. 'Prostitution and Civil Rights.' Michigan Journal of Gender and Law Symposium.

1991. Toward a Feminist Theory of the State. Cambridge: Harvard University Press.

2009. Trafficking, Prostitution, Inequality. Speech at Bihar, India.

Mahmood, Saba. Politics of Piety: The Islamic Revival and the Feminist Subject. Princeton: Princeton University Press, 2005.

Mcclintock, Anne. 1993. 'Sex Workers and Sex Work: Introduction.' Social Text 37: 1-10. 
Marcha Mundial das Mulheres. 2016. Offensive against the Mercantilisation of Women's Bodies. At http://www.marchamundialdasmulheres.org.br/wp-content/uploads/2016/08/images.pdf [Accessed on 2 October 2018].

Mohanty, Chandra T. 2012. 'Under Western Eyes: Feminist Scholarship and Colonial Discourses' Feminist Review 30: 61-88.

Moira, Amara. 2016. E Se Eu Fosse Puta. São Paulo: Hoo Editora.

Monteiro, Luana. 2014. Acusada de explorar travesti segue presa. CGN, 21 May. At https://cgn.inf. $\mathrm{br} /$ noticia/92091/acusada-de-explorar-travestis-segue-presa [Accessed on 2 October 2018].

Pelúcio, Larissa. 2010. 'Mover-se é luxo: travestis brasileiras e o mercado transnacional do sexo. Restrições, desafios e direito no cenário europeu contemporâneo.' In Horácio Costa, Berenice Bento, Wilton Garcia, Emerson Inacio, William Siqueira Peres (eds), Retratos do Brasil Homossexual: fronteiras, subjetividades e desejos. São Paulo; Edusp/ Imprensa Oficial, pp. 887-896.

2005. 'Na noite nem todos os gatos são pardos: notas sobre a prostituição travesti.' Cadernos Pagu 25: 217-248.

2012. 'Subalterno quem, cara pálida? Apontamentos às margens sobre pós-colonialismos, feminismos e estudos queer.' Contemporânea 2 (2): 395-418.

2014. 'Traduções e torções ou o que se quer dizer quando dizemos queer no Brasil?' Revista Periódicus 1 (1): 1-24.

2006. 'Três casamentos e algumas reflexões: notas sobre conjugalidade envolvendo travestis que se prostituem.' Revista Estudos Feministas 14 (2): 522-534.

Pentinnen, Elina. 2008. Globalization, Prostitution and Sex Trafficking: Corporeal Politics. Abingdon: Routledge.

Pereira, Pedro Paulo Gomes. 2012. 'Queer nos trópicos.' Contemporânea 2 (2): 371-394.

Peres, William Siqueira. 2012. 'Travestilidades nômades: a explosão dos binarismos e a emergência queering. Revista Estudos Feministas 20 (2): 539-547.

Perlongher, Néstor Osvaldo. 1986. O Negócio do Michê: Prostituição Viril em São Paulo. São Paulo: UNICAMP.

Piscitelli, Adriana. 2012. 'Feminismos e Prostituição no Brasil: Uma Leitura a Partir da Antropologia Feminista.' Cuadernos de Antropología Social 36: 11-31.

Preciado, Beatriz. 2014. Manifesto Contrassexual: Práticas Subversivas de Identidade Sexual. São Paulo: n-1 edições.

Rede Brasileira de Prostitutas. n.d. At http://www.redeprostitutas.org.br/ [Accessed on 2 October 2018].

Salamon, Gayle. 2010. Assuming a Body: Transgender and Rhetorics of Materiality. New York: Columbia University Press.

Silva, Hélio R. S. 2007. Travestis: Entre o Espelho e a Rua. Rio de Janeiro: Rocco.

Sjoberg, Laura. 2012. 'Toward Trans-gendering International Relations?' International Political Sociology 6 (4): 337-354.

Spivak, G C. 1988. 'Can the subaltern speak?' In C Nelson and L Grossberg (eds), Marxism and the Interpretation of Culture. Urbana: University of Illinois Press. 
Sylvester, Christine. 1996. 'The contributions of feminist theory to international relations.' In Steve Smith, Ken Booth and Marysia Zalewski (eds), International Theory: Positivism and Beyond. Nova York: Cambridge University Press.

United Nations General Assembly (UNGA). 2000. Protocol to Prevent, Suppress and Punish Trafficking in Persons Especially Women and Children, supplementing the United Nations Convention against Transnational Organized Crime. At https://www.ohchr.org/en/professionalinterest/pages/ protocoltraffickinginpersons.aspx [Accessed on 1 October 2018].

Weber, Cynthia. 2016. Queer International Relations: Sovereignty, Sexuality and the Will to Knowledge. New York: Oxford University Press.

Wilcox, Lauren. 2015. Bodies of Violence: Theorizing Embodied Subjects in International Relations. New York: Oxford University Press.

\section{About the author}

Amanda Álvares Ferreira is a PhD candidate in International Relations at the Pontifícia Universidade Católica do Rio de Janeiro (PUC-Rio), and is master in International Relations by the same institution. Her master's degree research has focused on Latin American feminist and decolonial theories as well as feminist thinking on prostitution and sex trafficking. Her current research is focused on theories of sovereignty and resistance within and without the discipline of International Relations, with a specific focus on theories and practices of gender and sexuality that relate to such themes. Other research interests are feminist and queer theory, studies of gender and sexuality, political theory, and theory of International Relations. 


\section{Tornando o Debate Queer: Analisando a Prostituição através de Sexualidades Dissidentes no Brasil}

Resumo: O objetivo deste artigo é contrastar discursos proeminentes sobre prostituição e tráfico de pessoas para o contexto da prostituição no Brasil e discursos feministas locais sobre esse assunto, entendendo suas contradições e limitações. Examinarei as experiências das prostitutas transgêneras brasileiras para abordar uma questão relacionada à agência que está subjacente nas teorizações feministas da prostituição: a prostituição pode ser livremente escolhida? É necessariamente exploradora? Meu argumento é que os discursos sobre o trabalho sexual, partindo de debates sobre tráfico sexual, estão fortemente engajados em uma lógica heteronormativa que pode ser incapaz de abordar a complexidade e a ambiguidade das experiências de prostitutas transgêneras e, portanto, não pode teorizar suas possibilidades de agência. Para tanto, vou fazer uma crítica à naturalização das normas de gênero que dificulta a compreensão das experiências que ultrapassam o binômio 'prostituta versus vítima.' Eu defendo como tanto uma solução abolicionista quanto uma solução legalizadora para as questões envolvidas no mercado do sexo, ao confiar no Estado como garantidor dos direitos das trabalhadoras do sexo, não podem responder às complexidades de um contexto como o brasileiro: quais concepções específicas de cidadania permitem que a violência contra grupos marcados sexualmente e racialmente aqui analisados possa ocorrer em tão grande escala.

Palavras-chave: Gênero; Prostituição; Tráfico Sexual; Teoria Queer; Feminismo; Travestis.

Received on 15 January 2018, and approved for publication on 28 August 2018.

\section{(cc) BY-NC} https://creativecommons.org/licenses/by-nc/4.0/ 